Old Dominion University

ODU Digital Commons

1977

\title{
Modes of Gulf Stream Intrusion Into The South Atlantic Bight Shelf Waters
}

Larry P. Atkinson

Old Dominion University, latkinso@odu.edu

Follow this and additional works at: https://digitalcommons.odu.edu/ccpo_pubs

Part of the Climate Commons, and the Oceanography Commons

\section{Original Publication Citation}

Atkinson, L. P. (1977). Modes of Gulf Stream intrusion into the South Atlantic Bight shelf waters.

Geophysical Research Letters, 4(12), 583-586.

This Article is brought to you for free and open access by the Center for Coastal Physical Oceanography at ODU Digital Commons. It has been accepted for inclusion in CCPO Publications by an authorized administrator of ODU Digital Commons. For more information, please contact digitalcommons@odu.edu. 


\section{MODES OF GULF STREAM INTRUSION INTO THE} SOUTH ATLANTIC BIGHT SHELF WATERS

Larry $P$. Atkinson

Skidaway Institute of Oceanography, P. O. Box 13687, Savannah, Georgia 31406

Abstract. Gulf Stream meanders and the associated vertical motions present water of varying densities at the shelf break along the southeast United States continental shelf. Under certain conditions of wind and Gulf Stream motion the vertically advected, deeper, Gulf Stream waters will intrude into these shelf waters. Depending on the ambient shelf water density the intruding water will override, interleave or form a bottom intrusion. Analysis of available hydrographic data indicates $20^{\circ} \mathrm{C}$ Gulf stream water could form a bottom intrusion anywhere along the coast except in January when shelf water densities are relatively higher. $24^{\circ} \mathrm{C}$ Gulf Stream water could only form bottom intrusions in April through November. The remainder of the year $24^{\circ} \mathrm{C}$ waters would interleave or override.

\section{Introduction}

The Gulf Stream, because of its great volume flow and persistence, dramatically influences the oceanography of the shallow shelf waters of the South Atlantic Bight (that area between Cape Hatteras and Cape Canavera1). Also, unlike the Gulf Stream north of Cape Hatteras, there is no slope water between the Gulf Stream waters and the shelf waters. The normal Gulf Stream position is adjacent to the continental shelf resulting in direct coupling between these waters. The intrusion of Gulf Stream water into the shelf waters (depths less than $50 \mathrm{~m}$ ) of the South Atlantic Bight was first recognized by Bumpus [1955] in his study of shelf circulation of the waters south of Cape Hatteras. Later, Webster [1961] made a more detailed study of meanders in Onslow Bay. Stefansson, Atkinson and Bumpus [1971], Blanton [1971] and Bumpus [1973] further described various properties of intrusions. This paper presents a conceptual model of Gulf Stream intrusions into the South Atlantic Bight based on several years of observation and discussion. It is stressed that in this paper we are not concerned with the particular cause of an intrusion be it topographic, wind or tidal.

\section{Data Base}

The data used in this study originates from many sources, the principle one beling four seasonal cruises in the north Florida, Georgia, South Carolina area [Atkinson, 1975, 1976].

Results and Discussion

\section{Presentation of Cold Water at the Shelf Break}

Our experience in sampling the shelf waters of the South Atlantic Bight has led us to recognize several situations under which the deeper Gulf

Copyright 1977 by the American Geophysical Union.
Stream waters ascend and intrude onto the shelf. The position of the Gulf Stream in the east/west (offshore/onshore) direction is important in determining the type of water overlying the shelf break. Easterly movements of the Stream apparently cause upward movement of isotherms and consequently colder water is upwelled at the shelf break. Westerly movements of the Stream cause a depression of isotherms and higher temperatures at the shelf break. Evidence for this often appears in vertical sections across the Stream. Figure 1 shows examples of vertical temperature sections across the shelf and Stream. In the upper section the Gulf Stream core is to the east and cold waters are advecting onto the shelf. In the lower section, the Gulf Stream core is located near the shelf break and the cold water is not present. To illustrate the vertica1 and horizontal coupling we have plotted the bottom temperature at the $50 \mathrm{~m}$ isobath vs the distance offshore at which the $20^{\circ} \mathrm{C}$ isotherm reaches a depth of $100 \mathrm{~m}$ (a criteria for the position of the Gulf Stream core) (Figure 2).
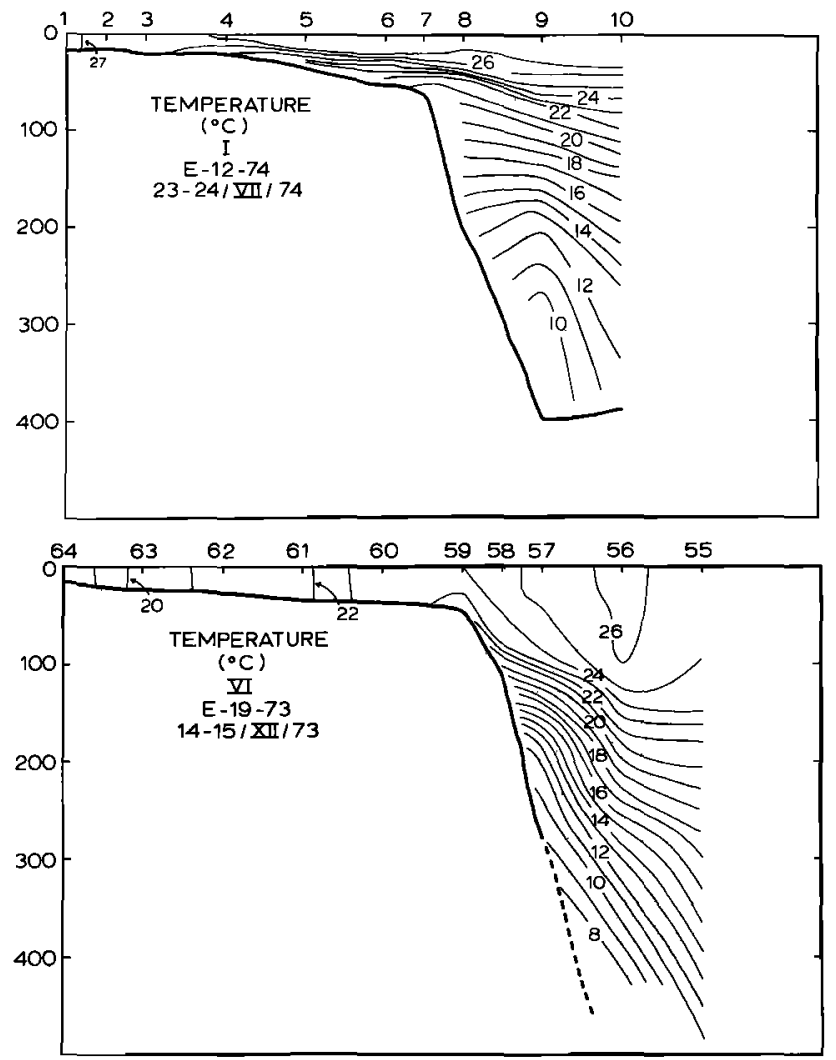

Fig. 1. Two examples of vertical temperature structure in the South Atlantic Bight. The E-1274 section is off Charleston, South Carolina and the E-19-73 section is off Brunswick, Georgia. Data from Atkinson $[1975,1976]$. 


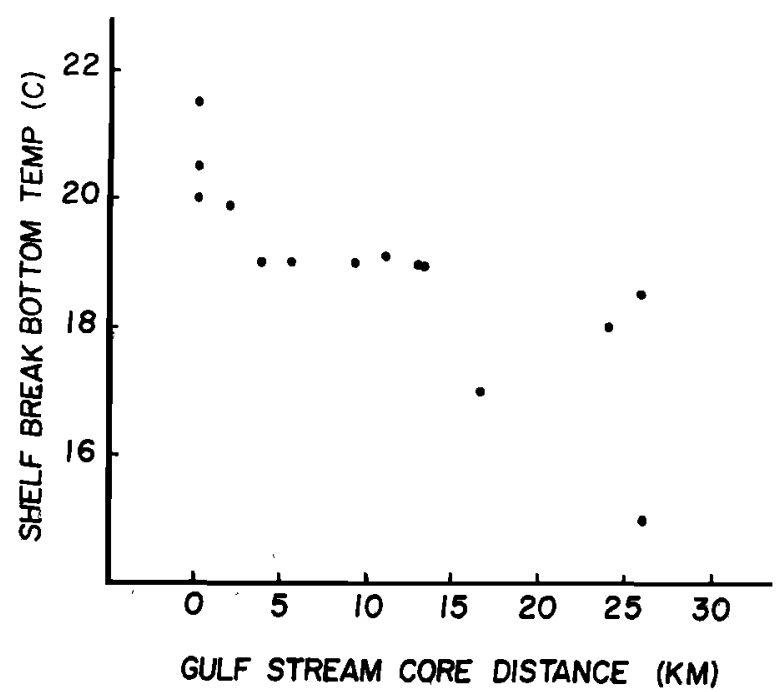

F1g. 2. Relation of the onshore/offshore position of the Gulf Stream to the near-bottom temperature at the shelf break $(50 \mathrm{~m})$. The lateral position of the Gulf Stream was the horizontal distance from the shelf break to the point at which the $20^{\circ} \mathrm{C}$ Isotherm reaches $100 \mathrm{~m}$ depth. Data from Atkinson $[1975,1976]$.

Ouf stations were not deep enough to allow use of the more traditional criteria of $18^{\circ} \mathrm{C}$ at $200 \mathrm{~m}$ depth. The treatment poses some problems since eddies [Lee, 1975] of ten make it difficult to determine the offshore position of the Stream. In this analysis we used the data from the four seasonal cruises (23 sections) and rejected those yertical sections that indicated the presence of an eddy ( 9 sections). Eddies were indicated by isotherms sloping down to the west (see $10-15^{\circ} \mathrm{C}$ water in upper panel, Figure 1). However, despite the inherent problems, it is clear that the nearshore positions of the Stream are associated with. higher bottom temperatures while lower pottom temperature are assoctated with various offshore positions. The low scatter in shelf break temperatures appear reasonable considering the number of temperature varying processes such as tidal, inertlal and wind induced motions.

\section{Modes of Gulf Stream Intrusion}

The Gulf Stream onshore/offshore motions produce changes in the water properties water at the shelf break. Movement of that water depends on the wind, subsequent Gulf Stream motion, and relative density differences between shelf water and Gulf Stream water. While wind and Gulf Stream motion may determine the horfzontal expanse of the intrustion across the shelf it is the shelf water density that determines the vertical mode of the intrusion. We have found three basic types of intrusions which are shown schematically in Figure 3.

Override (Intruding waters less dense) (Figure 3A): This mode is often found in the northern part of the South Atlantic Bight where shelf waters are relatively dense during the winter months because of the cooling of high salinity water. Override is occasfónally observed in the southern part of the Bight during abnormal cooling of high salinity shelf water. The central part of the Bight, which has lower salinities due to higher local runoff, apparently does not experience this type of intrusion.

Interlayering (Shelf stratified with intrusion of Intermediate density) (Figure 3B): Interlayering occaslonally is seen in the northern portion of the South Atlantic Bight particularly in Onslow and Raleigh Bays. Usua1ly relatively warm, high salinity, Gulf Stream is layered between the cold, high salinity shelf water on the bottom, and cold, low salinity surface waters above. The cold, low salinity surface waters is Virginia coastal water that orlginates north of Cape Hatteras and occasionally flows south around the Cape in respanse to strong northerly winter winds [Stefansson, Atkinson and Bumpus, 1971]. Whether the Gulf Stream water overrides the shelf water, then is in turn overridden by Virginia coastal water, or the Gulf Stream water interlayers between the two resident water masses is not known.

Bottom Intrusion (Intruding water more dense than shelf water) (F1gure 3C): The most dramatic process is the case in which the relatively cooler, high density Gulf stream water flows along the bottom beneath the resident shelf waters. This often occurs during the summer throughout the South Atlantic Bight and has been observed throughout the year in the southern section. The onshore extent of bottom intrusions are probably greater than override or interlayering.

Figure 1A (upper) shows an example of a bottom intrusion off Charleston, South Carolina in July 1974. The colder waters carried a high load of nutrients, causing high production and a very
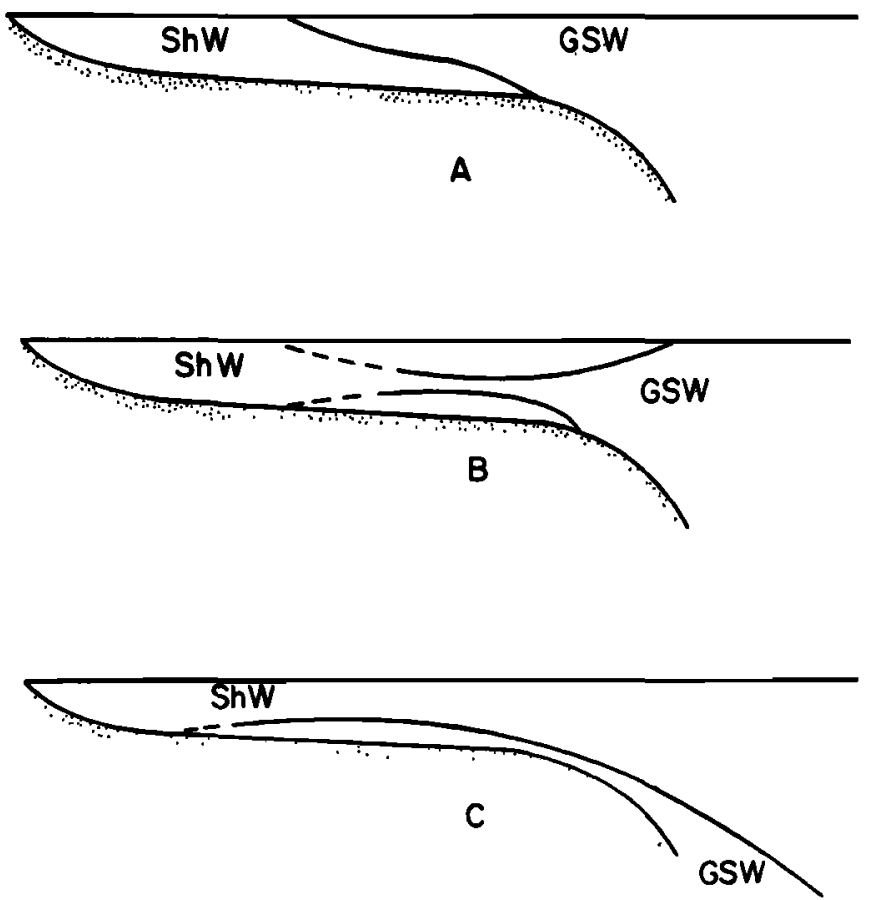

Fig. 3. Modes of Gulf Stream intrusion: a) override; b) interleaving; c) bottom intrusion. 

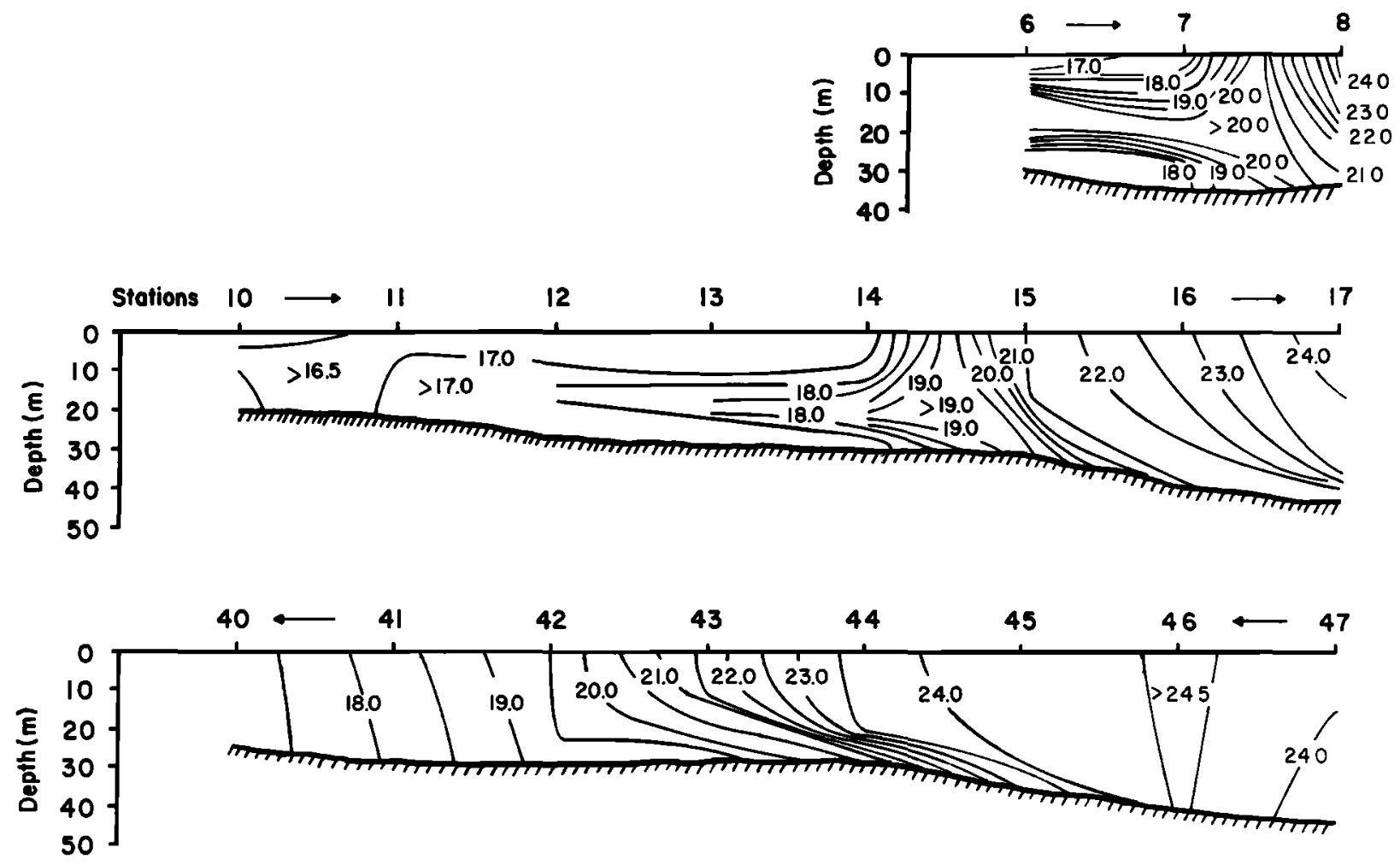

Fig. 4. Vertical temperature profiles showing interleaving and override. Upper two are interleaving examples and the lower shows override. Data from Atkinson, Singer and Pletrafesa [1976]. Distance between stations is $10 \mathrm{~km}$. Distance between sections is $20 \mathrm{~km}$.

stable water column. Figure 4 shows several vertical sections of Onslow Bay, North Carolina in December 1975. The upper section is just south of Cape Lookout and the lower ones are progressively further south in the Bay. The upper two sections are an example of interleaving with the high salinity Gulf Stream water flowing over the resident Onslow Bay water and then in turn overridden by cold, low salinity water that evidently is flowing south around Cape Lookout. The cold, low salinity water of northern origin was not present in the southern part of the Bay where override was observed. These cases of override are similar to those Stefansson et al. [1971] referred to as cascading and they may be the same phenomenon.

The above three modes in which intrusions operate are density dependent. Thus, since shelf water densities depend on regional runoff and temperature cycles, the mode of occurrence should be reasonably predictable. We examined the data set on file at the Skidaway Institute to determine the seasonal density changes in South Atlantic Bight shelf waters. Figure 5 is a combined plot of surface density values at all stations on file where the bottom depth is greater than $30 \mathrm{~m}$ and less than $40 \mathrm{~m}$. As expected, the shelf water density decreases during the summer months in response to heating and increased runoff. On the same plot we have indicated the density of typical, deeper Gulf Stream waters that may intrude onto the shelf. This shows that for much of the year $20^{\circ} \mathrm{C}$ Gulf Stream water could form a bottom intrusion except in December through February when shelf water densities are higher. Note that $24^{\circ} \mathrm{C}$ Gulf Stream water may only form bottom intrusions from April through November, the remainder of the year it would interleave or more likely override. This plot contains data from the entire $S A B$ thus regional differences are not evident. However, bottom intrusions may predominate in the southern $S A B$ because of the warmer, lighter shelf waters.

The observed variance of shelf surface water density that is maximfzed in the fall, winter and spring indicates, in itself, the variable effect of the Gulf Stream. During the winter months the density is quite variable because any location can be influenced by contrasting waters: low temperature, low salinity shelf water or high temperature, high salinity Gulf Stream water. During the summer months the variance is less in response to the decreased contrast of the two surface water masses (shelf and Gulf Stream).

\section{Conclusions}

We have shown there are three basic vertical modes of Gulf Stream intrusion into the South Atlantic Bight shelf waters. This does not preclude a multitude of variations of each but typifies our observations. The origin of intrusion events will not be clearly defined until knowledge of the easterly movement of the Gulf Stream meander motions are better understood. The question of how Gulf Stream eddies [Lee, 1975; Lee and Mayer, 1977] relate to intrusions is currently unanswerable since so little is know of them, their structure or origin. Eddies are of ten thought of as evolving from meanders and we do not know how intrusions depend on the 


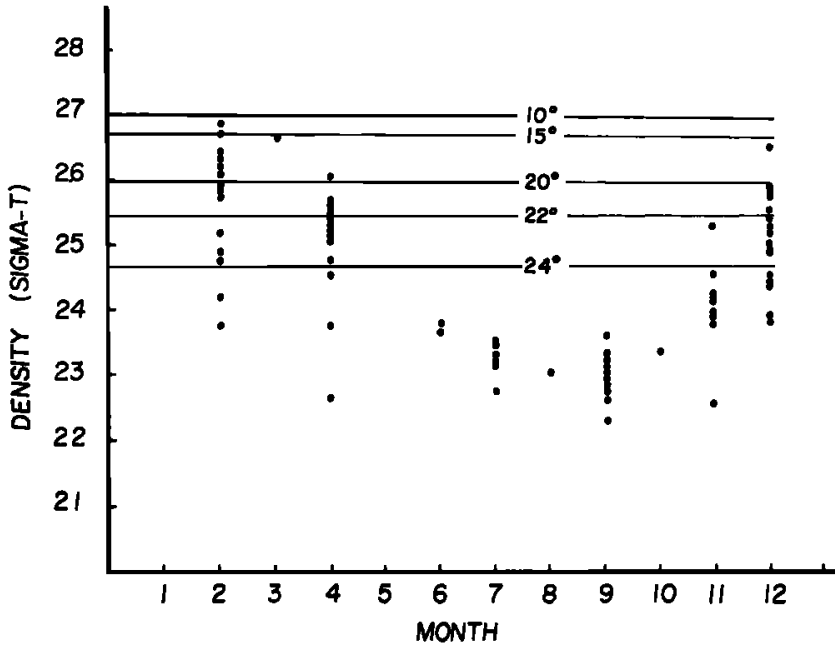

Fig. 5. Density of South Atlantic Bight shelf waters. Density of surface waters at stations where the water depth was 30 to $40 \mathrm{~m}$. Horizontal Iines indicate the density of Gulf Stream waters at the indicated temperature. Data from all major cruises in South Atlantic Bight (contact author for details).

meanders. Since most measurements to date have been from onshore/offshore sectlons with little alongshore detall the eddy structure may have been missed. In spite of these shortcomings in data, however, the general observations presented here appear valid.

Acknowlegdments. This research was supported by the U. S. Department of Energy (E(38-1)-889) and the Skidaway Institute of Oceanography. I would like to thank Drs. D. W. Menze1, J. 0 . Blanton, T. N. Lee and L. J. Pletrafesa for the valuable discussion and criticism. Mr. W. Chandler and $J$. Singer assisted with the data analysis.

Ship time for the EASTWARD cruises was provided by the Duke UnIversity Marine Laboratory
Cooperative Oceanography Program (NSF GA-27725). Drafting was by Mr. D. McIntosh and typing by Ms. P. Vopelak.

\section{References}

Atkinson, L. P., Oceanographic observations in the Georgla Bight, R/V EASTWARD cruises E-1373 and E-19-73. Georgia Marine Science Center Technical Report 75-6, 1975.

Atkinson, L. P., Oceanographic observations in the Georgia Bight, R/V EASTWARD cruises E-3-74 and E-12-74. Georgia Marine Sclence Center Technica] Report 76-1, 1976.

Atkinson, L. P., J. J. Singer and L. J. Pletrafesa, Onslow Bay Intrusion study hydrographic observations during current meter servicing cruises in August, October and December 1975: OBIX I, III and IV. Georgia Marine Sclence Center Technical Report 76-4, 1975.

Blanton, J. O., Exchange of Gulf Stream Water with North Carolina Shelf Water in Onslow Bay during stratifled conditions, Deep-Sea Res., $18,167-178,1971$.

Bumpus, D. F., The circulation over the continental shelf south of Cape Hatteras, Trans., Am. Geophys. Un., 36, 601-611, 1955.

Bumpus, D. F., A description of the circulation on the continental shelf of the east coast of the U. S., In: Progress in Oceanography, 6 , $11-57,1973$.

Lee, T. N., Florida Current spin-off eddies, Deep-Sea Res. , 22, 753-765, 1975.

Lee, T. N. and D. A. Mayer, Low-frequency current variability and spin-off eddies along the shelf off Southeast Florida, J. Mar. Res., 35, 193-220.

Stefansson, U., L. P. Atkinson and D. F. Bumpus, Seasonal studies of the hydrographic properties and circulation of the North Carolina shelf and slope waters, Deep-Sea Res., 18, 383-420, 1971.

Webster, F., A description of Gulf Stream meanders off Onslow Bay, Deep-Sea Res., $\underline{8}$, 130-143, 1961.

(Received August 22, 1977; accepted Dctober 10, 1977.) 